\title{
Multi-year succession of cyanobacteria blooms in a highland reservoir with changing nutrient status, Guizhou Province, China
}

\author{
Shengxing LONG, ${ }^{1}$ Paul B. HAMILTON, ${ }^{2}$ Yang YANG,${ }^{1 *}$ Jianrong MA,${ }^{3}$ Ondhoro C. CHOBET, ${ }^{4}$ Chuan CHEN, 5 \\ Zhiwei LIU, ${ }^{1}$ Xian DONG, ${ }^{5}$ Anzhi DANG, ${ }^{5}$ Jingan $\mathrm{CHEN}^{6}$ \\ ${ }^{1}$ College of life Science and Technology, Jinan University, Guangzhou, Guangdong 510632, China; ${ }^{2}$ Canadian Museum of Nature, \\ P.O. Box 3443, Station D, Ottawa, Ontario K1P 6P4, Canada; ${ }^{3}$ Key Laboratory of Reservoir Aquatic Environment, Chongqing \\ Institute of Green and Intelligent Technology, Chinese Academy of Sciences, Chongqing, 400714, China; ${ }^{4}$ Buginyanya Zonal \\ Agricultural Research and Development Institute, P.O. BOX 1356, Mbale, Uganda; ${ }^{5}$ Guizhou Normal University, Guiyang, Guizhou \\ 550001, China; ${ }^{6}$ Institute of Geochemistry Chinese Academy of Sciences, Guiyang, Guizhou 550001, China \\ *Corresponding author: yangyang@scies.org
}

\begin{abstract}
Over the last 22 years significant phytoplankton changes in Hongfeng lake reservoir have been observed with multiple years of harmful cyanobacteria blooms (cHABs). Fish farming and other anthropogenic activities from 1994-2001 triggered the harmful blooms. Nine years after the cessation of aquaculture, a conversion from problematic species (Microcystis spp, Aphanizomenon flos-aquae) to the less problematic species $P$. limnetica and other associated non-cyanobacteria taxa was recorded. Through this period of change, trophic factors (bottom-up) were re-examined, and correlations between cHABs and selected environmental variables were observed. Higher temperatures, nutrients [total nitrogen (TN), total phosphorus (TP)] and available light significantly favored the development of Microcystis spp blooms. With declining nutrient loads, and a decline in TP relative to TN there was a competitive shift from Microcystis summer blooms to the growth of Pseudanabaena limnetica and other non-cyanobacteria. Pseudanabaena limnetica was favored over Microcystis spp when temperatures were $<20^{\circ} \mathrm{C}$ and $\mathrm{TP}$ was $<0.03 \mathrm{mg} \mathrm{L}{ }^{-1}$. The apparent species succession to $P$. limnetica was enhanced by a competitive advantage under varied light conditions. Multiple environmental and biotic conditions (not always nutrients) were driving cHABs. Although only a selected number of environmental variables were examined, the CCA analysis supports observations that temperature and nutrients were associated with the species shift. The replacement of cHABs with the growth of less toxic cyanobacteria like $P$. limnetica, and other algae creates an interesting scenario (new community condition) for the removal of problematic taxa in reservoir systems. Diverting or controlling blooms will have direct implications on water quality and economic remediation initiatives in reservoir and lake management.
\end{abstract}

Key words: Aphanizomenon; competitive succession; cyanobacteria blooms; Microcystis; nitrogen and phosphorus; Pseudanabaena.

Received: March 2017. Accepted: January 2018

\section{INTRODUCTION}

Cyanobacteria are the most ancient primary producers on the planet and can form harmful algal blooms (cHABs) in freshwater, estuarine and marine ecosystems (O’Neil et al. 2012; Reynolds and Walsby, 1975). Harmful algal blooms have been reported in the scientific literature for more than 130 years (Francis, 1878; O'Neil et al., 2012) and are presently increasing in occurrence events across freshwater systems (Hallegraeff, 1993; Paerl and Huisman, 2009). These blooms are associated with poor water quality, accumulation of aquatic biomass and low saturated oxygen levels (Jonas et al., 2014; Wiegand and Pflugmacher, 2005). Cyanobacteria under certain conditions can also produce toxins which along with taste and odor compounds have negative biological and human health effects (Jonas et al., 2014; Pick, 2016; Wiegand and Pflumacher, 2005). Massive proliferations of harmful algae in freshwater and marine ecosystems have caused losses to natural resources, national economies, and resulted in human sickness and death worldwide (Bláha et al., 2009; Lewitus et al., 2012; Ma et al., 2014). A previous study has shown that biological and economic losses due to HABs were estimated at US\$82 million annually in the United States and nearly US\$813 million annually in Europe (Hoagland and Scatasta, 2006).

Two contributors to cHABS, Aphanizomenon flosaquae Ralfs ex Bornet \& Flahault and Microcystis spp have been correlated to increased nutrient inputs, especially phosphorus and nitrogen (Liqiang et al., 2003; Conley et al., 2009; Ma et al., 2015; O'Neil et al., 2013). Paerl and Huisman (2009) and Pick (2016) also attributed climate change (warmer temperatures) to changes in hydrological cycles and blooms. Further, Knoll et al. (2008) have associated cHABs to invasive species events. 
Blooms are complex events, typically not caused by a single environmental driver but rather a series of factors occurring concurrently (Heisler et al., 2008; O'Neil et al., 2012). The reservoir with cHABs concern in this study, Hongfeng Lake (Guizhou Province), is a typical Karst plateau deep water reservoir. The reservoir has been a water source for the City of Guiyang since 1960 with presently no public, industrial or recreational use In 1994, fish cages for aquaculture were deployed in Hongfeng Lake reservoir and remained until 2001. This aquaculture practice caused extensive cHAB blooms (Aphanizomenon flos-aquae and Microcystis spp) during and after the period of fish culturing. This single anthropogenic impact has dramatically changed the quality of this economic water source.

Studies examining the decline and termination of cyanobacteria blooms have primarily focused on the effects of nutrients and other environmental factors, particularly on the decrease of available phosphorus. In contrast, studies looking at biological interactions related to algal blooms are rare (e.g. Proulx et al. 1996). The objective of this study was to evaluate the temporal and spatial occurrence of cHAB competitive succession in Hongfeng Lake reservoir in relation to nutrients and environment. Specifically what temporal scale of change was observed and the implications for recovery and improvement of water quality in other manipulated reservoir systems.

\section{METHODS}

\section{Study site}

Hongfeng Lake reservoir $\left(26^{\circ} 24^{\prime}-26^{\circ} 34^{\prime} \mathrm{N}, 106^{\circ} 20^{\prime}-\right.$ $\left.106^{\circ} 26^{\prime} \mathrm{E}\right)$, is located in Guiyang City, Guizhou Province, southwest China (Fig. 1). This is one of many reservoirs built on the Maotiao River, its closest neighbor is Baihua Reservoir ( $\sim 20 \mathrm{~km}$ downstream). Hongfeng reservoir is a deep-water impoundment $(45 \mathrm{~m})$ with limestone and dolomite as the dominant bedrock. The local soils are calcareous, with high $\mathrm{pH}$ (Liu et al., 2012). Water storage in the reservoir was initiated in 1960, providing local communities with hydropower, fisheries, irrigation, drinking water, and recreation resources. The five main fish species are Cyprinus carpio L (Common carp), Carassius auratus L. (Goldfish), Ctenopharyngodon idella Valenciennes (Grass Carp) Aristichthys nobilis (Richardson) (Bighead Carp), and Hypophthalmichthys molitrix Valenciennes (Silver Carp). The regional watershed surface area is 1596 $\mathrm{km}^{2}$, reservoir water surface area $57.2 \mathrm{~km}^{2}$, reservoir mean depth of $24 \mathrm{~m}$, and maximum depth of $45 \mathrm{~m}$ (Fang and $\mathrm{Li}$, 2009; Liu et al., 2012; Lu et al., 2007).

We utilized reported studies (our work and others) over the past 35 years from Hongfeng Lake reservoir, including new data collected by our group from 20072014 , in this study. The dataset included physical and chemical factors as well as phytoplankton community

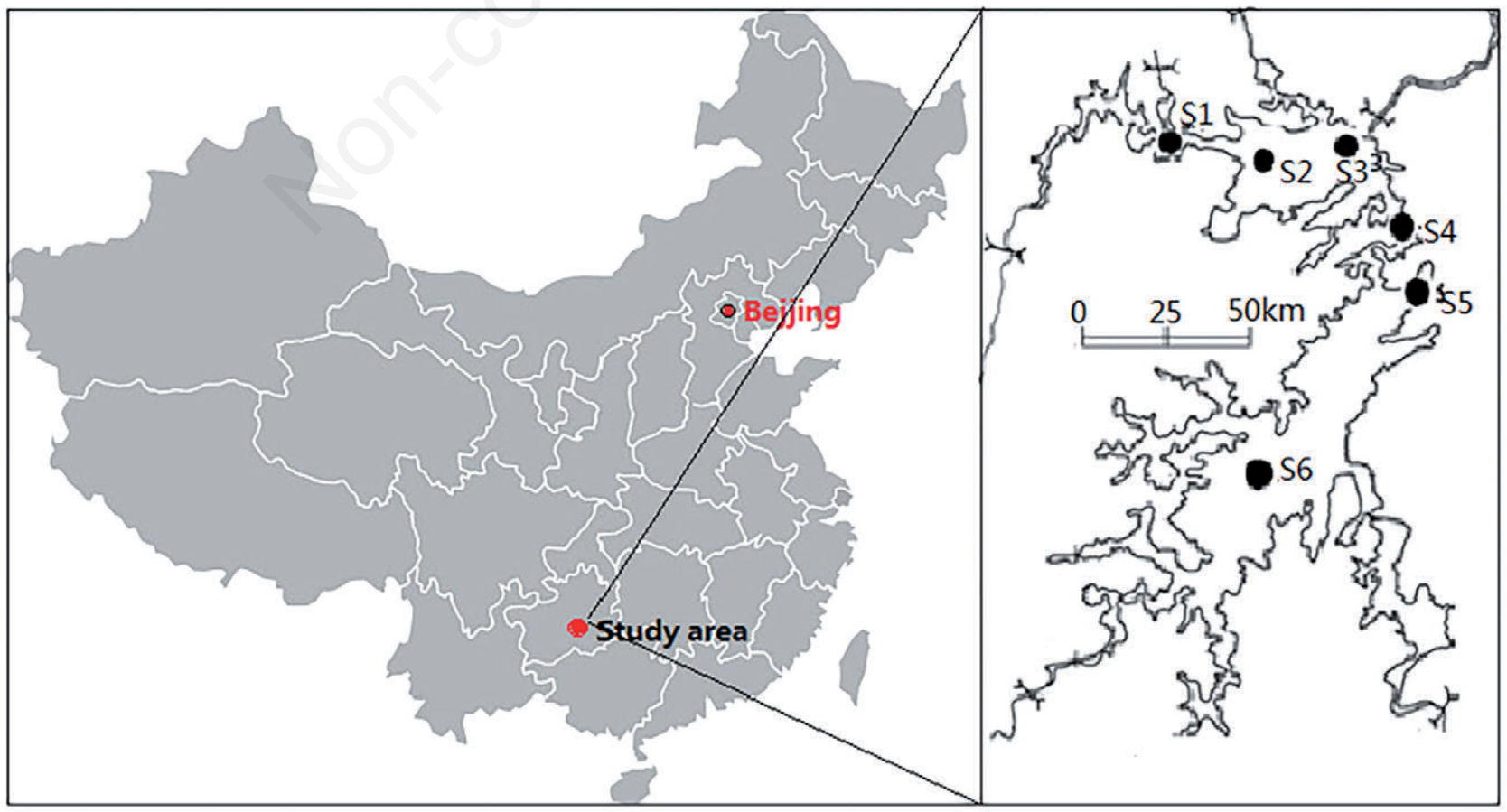

Fig. 1. Lake Hongfeng. Locations of the study sites in the reservoir, sites S1 to S6. 
composition. In this study, a cyanobacteria bloom was defined as a dense blue-green colored surface layer with chlorophyll- $a$ concentrations in excess of $10 \mu \mathrm{g} \mathrm{L}^{-1}$, or with cell densities that exceed $1.510^{7}$ cells L ${ }^{-1}$ (Australian and New Zealand Environment and conservation council, Canberra, 1992). Air temperatures around Guiyang have shown no significant annual differences from 1961-2011, with winter temperatures $13.9-16.5^{\circ} \mathrm{C}$, and a mean of $22.5^{\circ} \mathrm{C}$ in the summer (Guiyang City, June-August, 25$30^{\circ} \mathrm{C}$ ) (Li et al., 2013). Water levels in the reservoir from 1961-1979 were on average 1237.3 units and during the study period from 2008-2010, 1237.2 units ( $\mathrm{SD} \pm 1.8$ ).

Sampling sites from 2005-2014 were along six transects $(\mathrm{n}=12)$ perpendicular to the longitudinal axis of the lake [S1 $\left(26^{\circ} 33^{\prime} 18^{\prime \prime} \mathrm{N}, 106^{\circ} 21^{\prime} 20^{\prime \prime} \mathrm{E}\right)$; S2 $\left(26^{\circ} 32^{\prime} 49^{\prime \prime} \mathrm{N}\right.$, $\left.106^{\circ} 23^{\prime} 01^{\prime \prime} \mathrm{E}\right) ; \quad \mathrm{S} 3 \quad\left(26^{\circ} 32^{\prime} 47^{\prime \prime} \mathrm{N}, 1^{\circ} 6^{\circ} 25^{\prime} 34^{\prime \prime} \mathrm{E}\right) ; \quad$ S4 $\left(26^{\circ} 31^{\prime} 38^{\prime \prime} \mathrm{N}, \quad 106^{\circ} 26^{\prime} 03^{\prime \prime} \mathrm{E}\right) ; \quad$ S5 $\quad\left(26^{\circ} 30^{\prime} 50^{\prime \prime} \mathrm{N}\right.$, $\left.106^{\circ} 26^{\prime} 20^{\prime \prime} \mathrm{E}\right)$; S6 (26 29'09"N, 106 25'17"E)] (Fig. 1).

\section{Samples preparation and analysis}

Sampling for phytoplankton and water quality was once every week from August 2008 to December 2009 (Tab. 1). In other years (2010 - 2014) phytoplankton samples were collected once every season (Tab. 1). Phytoplankton sampling included two parts. First, samples for qualitative species analysis were collected as follows: a phytoplankton net (64 $\mu \mathrm{m}$ mesh) was submerged to 50 cm under the water surface in " $\infty$ " formation. The net was lifted slowly from the water vertically to limit backwash.
The samples were then fixed using methanol: glycerin:distilled water=1:1:8. Phytoplankton were identified according to the alga-flora of Hu et al. (1980). Part two, $1 \mathrm{~L}$ bottles of phytoplankton were collected from the water surface $(0.5 \mathrm{~m})$, mid-depth $(8 \mathrm{~m})$ and bottom $(16$ $\mathrm{m})$ to determine community composition, abundance and biomass. Phytoplankton samples were preserved with Lugol's iodine solution, then isolated through sedimentation for $48 \mathrm{~h}$ and concentrated to a final volume of $30 \mathrm{~mL}$. The density of individual cells for each taxon was measured with a Sedgwick-Rafter counting chamber under magnifications of 200-400×. Total algal biovolumes for each species were calculated from cell numbers and cell size measurements. Biomass was calculated from species shapes converted to biovolumes (Hillebrand et al., 1999). The final conversion to biomass assumed that 1 $\mathrm{mm}^{3}$ of volume was equivalent to $1 \mathrm{mg}$ of fresh weight biomass (Papista et al., 2002).

Physico-chemical parameters, including water temperature (WT), dissolved oxygen (DO), and $\mathrm{pH}$ were measured in situ with a Yellow Springs Instruments (YSI) 6600 multi-sensor sonde (Yellow Springs Inc, Yellow Springs, OH, USA). Light intensity was measured using a ZDS-10W underwater light meter (lux) and converted to photosynthetic photon density using the following formula: $1000 \mathrm{lux} \approx 19.53 \mu \mathrm{mol} \mathrm{m}^{-2} \mathrm{~s}^{-1}$. In the lab, TN, $\mathrm{TP}$ and $\mathrm{NH}_{3}-\mathrm{N}$ were quantified using the alkaline potassium persulfate oxidation method (Ma et al., 2014). Chlorophyll- $a$ (chl- $a$ ) was analyzed by spectrophotometry after extraction in $90 \%$ acetone (Ma et al., 2014).

Tab. 1. Sample dates for this study from 2007 to 2014 .

\begin{tabular}{|c|c|c|c|c|c|c|c|}
\hline Sample & Date & Sample & Date & Sample & Date & Sample & Date \\
\hline SA1-5 & Aug.-Dec. 2007 & SA6-11 & Feb.-Jul. 2008 & SA13-22 & Mar.-Dec. 2010 & $\begin{array}{l}\text { SA23, } \\
\text { SA24, } \\
\text { SA25, }\end{array}$ & $\begin{array}{l}\text { Jan. } 2013 \\
\text { Apr. } 2013 \\
\text { Jan. } 2014\end{array}$ \\
\hline $\mathrm{S} 0$ & $29 / 07 / 2008$ & S 15 & $15 / 11 / 2008$ & S 30 & $17 / 05 / 2009$ & SA26, & Aug. 2014 \\
\hline $\mathrm{S} 1$ & $05 / 08 / 2008$ & S 16 & $29 / 11 / 2008$ & S 31 & $24 / 05 / 2009$ & $\mathrm{~S} 45$ & $30 / 08 / 2009$ \\
\hline $\mathrm{S} 2$ & $12 / 08 / 2008$ & S 17 & $13 / 12 / 2008$ & S 32 & $30 / 05 / 2009$ & S 46 & $05 / 10 / 2009$ \\
\hline S 3 & $19 / 08 / 2008$ & S 18 & $27 / 12 / 2009$ & S 33 & $07 / 06 / 2009$ & S 47 & $11 / 12 / 2009$ \\
\hline $\mathrm{S} 4$ & $26 / 08 / 2008$ & S 19 & $09 / 01 / 2009$ & S 34 & $14 / 06 / 2009$ & S 48 & $03 / 01 / 2010$ \\
\hline S 5 & $02 / 09 / 2009$ & $\mathrm{~S} 20$ & $11 / 02 / 2009$ & S 35 & $21 / 06 / 2009$ & S 49 & $05 / 01 / 2011$ \\
\hline S 6 & $06 / 09 / 2009$ & S 21 & $28 / 02 / 2009$ & S 36 & $28 / 06 / 2009$ & S 50 & $07 / 04 / 2011$ \\
\hline S 7 & $13 / 09 / 2009$ & S 22 & $14 / 03 / 2009$ & S 37 & $05 / 07 / 2009$ & S 51 & $06 / 07 / 2011$ \\
\hline S 8 & $20 / 09 / 2008$ & S 23 & $22 / 03 / 2009$ & S 38 & $12 / 07 / 2009$ & S 52 & $15 / 12 / 2011$ \\
\hline S 9 & $29 / 09 / 2008$ & S 24 & $26 / 03 / 2009$ & S39 & $17 / 07 / 2009$ & S 53 & $09 / 01 / 2012$ \\
\hline S 10 & $04 / 10 / 2008$ & S 25 & $04 / 04 / 2009$ & $\mathrm{~S} 40$ & $26 / 07 / 2009$ & S 54 & $10 / 04 / 2012$ \\
\hline S 11 & $11 / 10 / 2008$ & S 26 & $19 / 04 / 2009$ & S 41 & 03/08/2009 & S 55 & $08 / 07 / 2012$ \\
\hline S 12 & $18 / 10 / 2008$ & S 27 & $25 / 04 / 2009$ & $\mathrm{~S} 42$ & $10 / 08 / 2009$ & S 56 & $15 / 07 / 2013$ \\
\hline S 13 & $25 / 10 / 2008$ & S 28 & $05 / 05 / 2009$ & S 43 & $18 / 08 / 2009$ & S 57 & $15 / 11 / 2013$ \\
\hline S 14 & $01 / 11 / 2008$ & S 29 & $10 / 05 / 2009$ & S 44 & $25 / 08 / 2009$ & S58 & $05 / 04 / 2014$ \\
\hline
\end{tabular}


Additional data from 1980-2004 was also examined using previous research (Chen et al., 1998; Chen et al., 2008; Li, 2001; Liang et al., 1998; Liang et al., 1999; Liao et al., 2004; Long et al., 2013; Pang and Pang, 2007; Shen et al., 2006; Shi and Wu, 1982; Wu et al., 2004; Zhou et al., 1987).

\section{Statistical analysis}

Statistical analyses were conducted using the software SPSS 18.0 (PASW), Origin 8.0, and Canoco for windows 4.5. Phytoplankton biomass, Chl- $a$ along with physical and chemical parameters (TN, TP, $\mathrm{NH}_{3}-\mathrm{H}, \mathrm{pH}$ and water temperature) were averaged $(\mathrm{n}=12)$ for sites and depths (S1-S6) on each sampling date. SPSS 18.0 was used to analyze environment and species associations using $\mathrm{P}$ values before Canonical Correspondence Analysis (CCA). CCA analysis examined relationships between species and environmental factors. Canoco for windows 4.5 was used for principal component analysis (PCA) and detrended correspondence analysis (DCA). Principal component analysis was performed to detect major gradients among the environmental variables (Ter Braak and Prentice, 1988) as well as to detect outliers (Birks et al., 1990). Detrended correspondence analysis with detrending by segments and down-weighting of rare taxa was performed to examine patterns in the data, and to determine the maximum amount of variation within the species composition data. The gradient length of the main

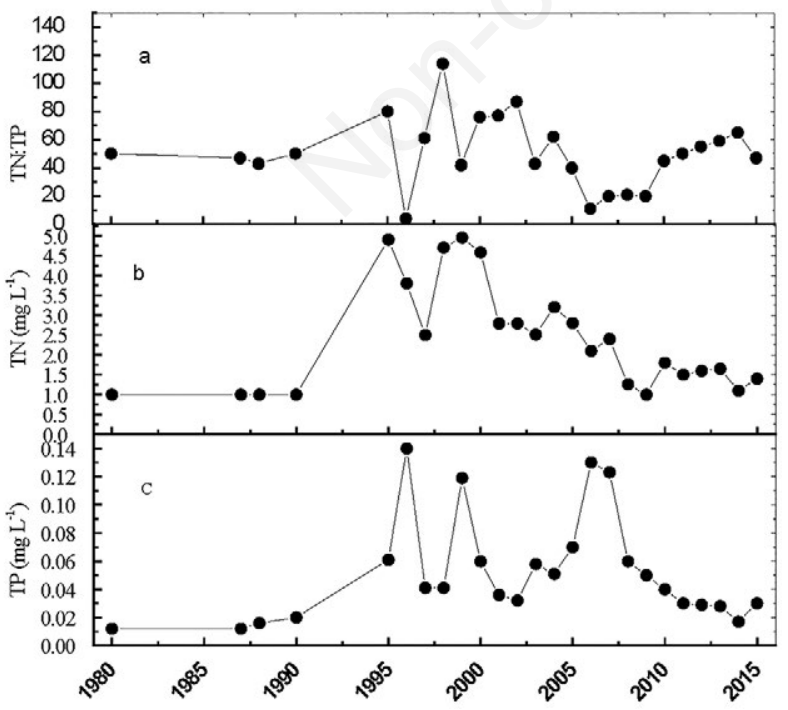

Fig. 2. TP, TN and TN:TP (mean of all sample sites) in Lake Hongfeng reservoir, China from 1980-2015. Additional data obtained from Zhou et al. (1987), Chen et al. (1998), Liang et al. (1998), Liang et al. (1999), Li (2001), Liao et al. (2004), Wu et al. (2004), Shen et al. (2006), Long et al. (2013).
DCA ordination axes (2.0-4.0) determined that CCA unimodal models would be applied (Ter Braak and Prentice, 1988).

\section{RESULTS}

\section{Environmental conditions 1980-2015}

Total nitrogen and TP concentrations were vastly different from 1980 to $2015(\mathrm{P}<0.0001)$. In 1980, TN concentrations were approx. $1.0 \mathrm{mg} \mathrm{L}^{-1}$ (Fig. 2b) while TP concentrations were $<0.02 \mathrm{mg} \mathrm{L}^{-1}$ (Fig. 2c). Prior to 1994, cyanobacterial blooms were not reported. In 1994, largescale fish cages for aquaculture were deployed in Hongfeng Lake reservoir. The use of feedstock with high $\mathrm{P}$ and $\mathrm{N}$ (4.5\% and $7 \%$, respectively, Zhong et al., 2004) increased nutrient loads in the reservoir. At the peak of additions, TP levels were $0.14 \mathrm{mg} \mathrm{L}^{-1}$ and $\mathrm{TN}$ reached $4.9 \mathrm{mg} \mathrm{L}^{-1}$. Seasonal cyanobacterial blooms consistently occurred from $1994-2009$ and were associated with elevated TP and TN (Fig. 2, Tab. 1). In order to better understand annual bloom dynamics in Hongfeng Lake reservoir, water quality measurements were collected biweekly (total 59 sample dates) from August 2007 to December 2009. Cyanobacterial blooms occurred when mean surface and mid-water concentrations of TN were $1.15 \mathrm{mg} \mathrm{L}^{-1}$ or greater and TP concentrations were $0.054 \mathrm{mg} \mathrm{L}^{-1}$ or greater (Figs. 3-6). The bottom waters during periods of cyanobacterial blooms had a mean TN concentration of $1.32 \mathrm{mg} \mathrm{L}^{-1}$ and mean TP concentration of $0.079 \mathrm{mg} \mathrm{L}^{-1}$ (Fig. 7). Chlorophyll- $a$ concentrations $\left(>10 \mu \mathrm{g} \mathrm{L}^{-1}\right)$ during bloom periods in surface waters were significantly higher than concentrations in midand bottom waters (Figs. 5a, 6a, 7a). After 2009, Microcystis and Aphanizomenon blooms declined, with significant reductions in TP (mean $0.033 \mathrm{mg} \mathrm{L}^{-1}$ surface waters, 0.028 $\mathrm{mg} \mathrm{L}{ }^{-1}$ mid-depths and $0.036 \mathrm{mg} \mathrm{L}^{-1}$ in bottom waters) (Figs. 5c, 6b, 7b). In contrast mean TN levels increased slightly (mean $1.59 \mathrm{mg} \mathrm{L}^{-1}$ in surface waters, $1.57 \mathrm{mg} \mathrm{L}^{-1}$ in mid-depth, and $1.50 \mathrm{mg} \mathrm{L}^{-1}$ in bottom waters) (Figs. 5b, $6 \mathrm{~b}, 7 \mathrm{~b})$. The nitrogen-phosphorus (N:P) ratio ranged from 4-114 with a mean of 40 between 1980-2014; there was no significant relationship between cyanobacterial bloom and TN:TP ratio (Figs. 2a, 3a).

Water temperatures were important for phytoplankton growth (Fig. 8a). Annually, temperatures in Hongfeng Lake reservoir ranged from Summer $>$ Autumn $>$ Spring $>$ Winter. Microcystis biomass increased with increasing water temperatures and to a lesser extent increasing $\mathrm{TP}$ and $\mathrm{NH}_{3}$ $\mathrm{N}$ (Fig. 9). Chlorophyll- $a$ concentrations exceeded $10 \mu \mathrm{g}$ $\mathrm{L}^{-1}$ when surface water temperatures were $>11^{\circ} \mathrm{C}$ (exceptions Jan. 2012 and Apr. 2014) (Fig. 5a). In general, chlorophyll- $a$ concentrations increased when water

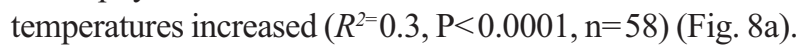
Chlorophyll- $a$ exceeded $20 \mathrm{~g} \mathrm{~L}^{-1}$ when temperatures were 
above $17^{\circ} \mathrm{C}$.There was also a significant relationship between Chlorophyll- $a$ concentration and higher water temperatures in mid- and bottom waters (Figs. 6a, 7a).

Hongfeng Lake reservoir was alkaline with mean $\mathrm{pH}$ values of $8.4,8.3$ and 8.0 in surface, mid-depths and bottom waters respectively (Figs. 5a, 6a, 7a). In surface waters, $\mathrm{pH}$ values increased when chlorophyll- $a$ increased $\left(R^{2=} 0.23, \mathrm{P}<0.0001, \mathrm{n}=58\right)$ (Fig. 8d). No significant $\mathrm{pH}$ changes were associated with enhanced chlorophyll- $a$ in mid- and bottom waters $(\mathrm{P}>0.05)$.
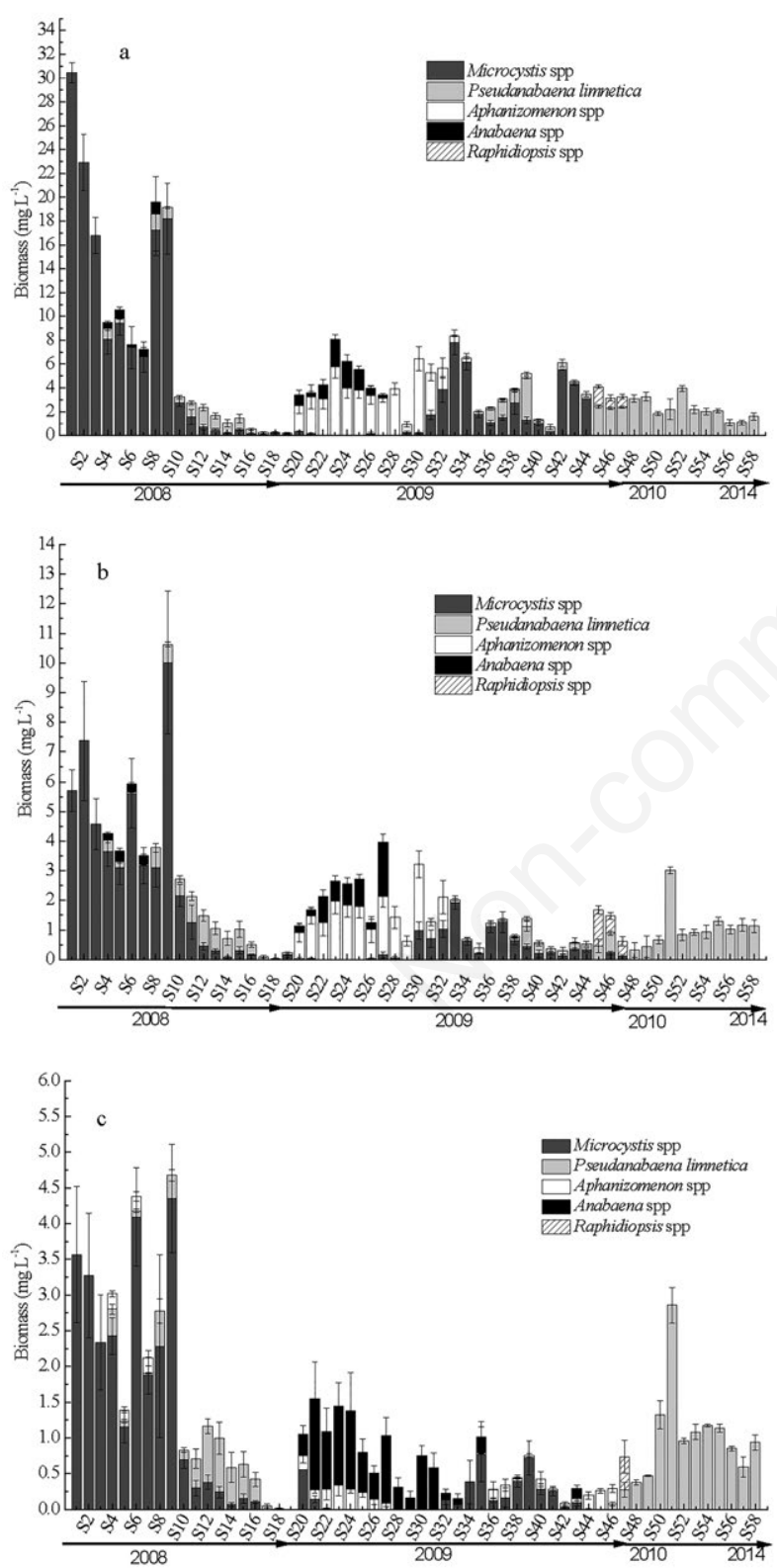

Fig. 3. Biomass of Cyanophyta (a surface, b middle, c bottom water) in Lake Hongfeng reservoir, China, 2008-2014. Each datum represents the mean of six sample sites with standard errors).
Dissolved oxygen levels in surface waters were consistently higher than mid-depth and bottom waters, with mean levels of 7.6, 7.1 and $5.1 \mathrm{mg} \mathrm{L}^{-1}$ respectively. Since oxygen was present in bottom waters the reservoir was mixed (Figs. 5a, 6a, 7a). There was no DO correlation with total phytoplankton biomass throughout the water column. However, there was a DO correlation with the biomass of diatoms and Pseudanabaena limnetica (Lemmermann) Komárek (Fig. 9c).

$\mathrm{NH}_{3}-\mathrm{H}$ concentrations in Hongfeng Lake reservoir
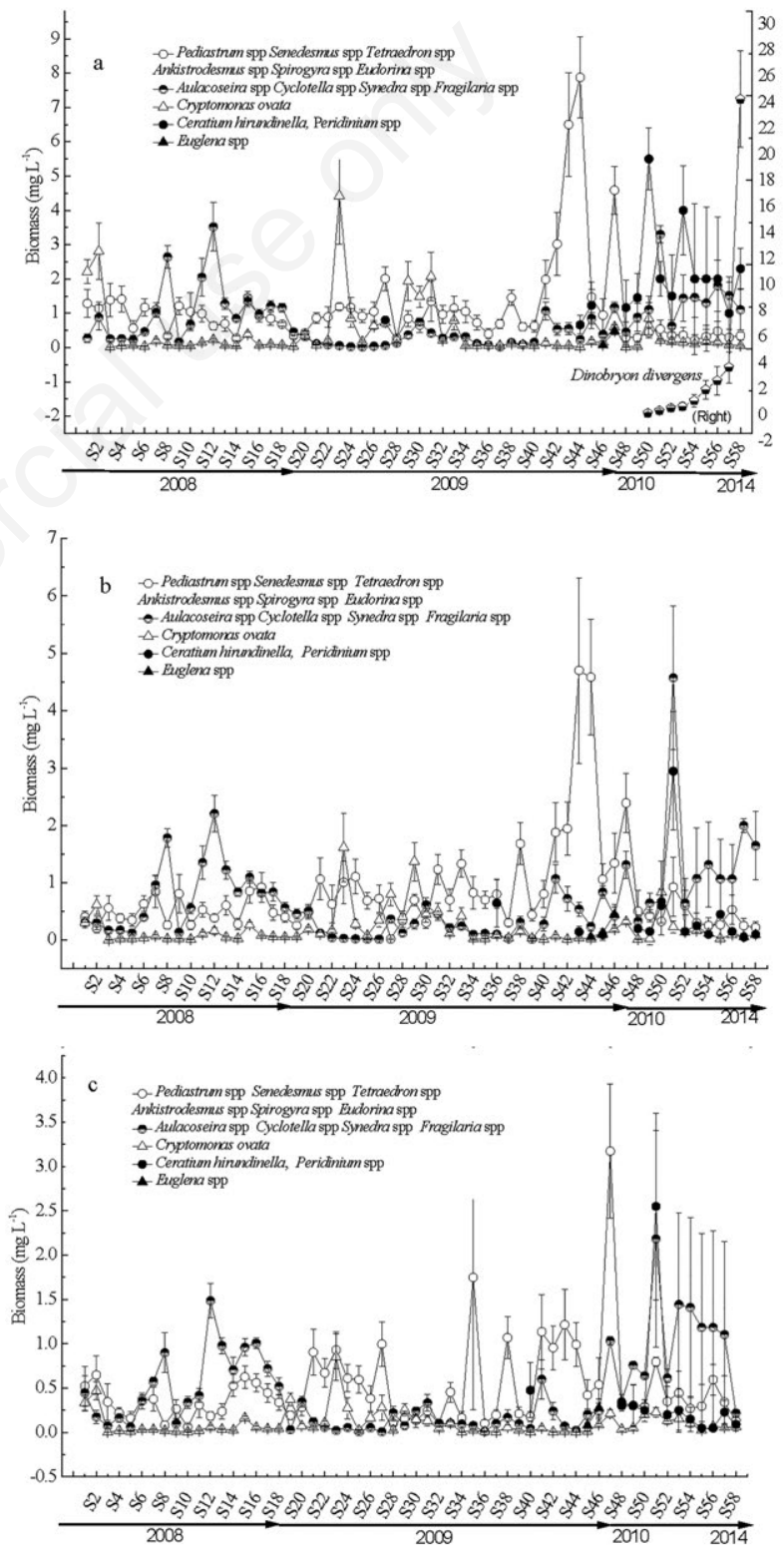

Fig. 4. Biomass of phytoplankton (a surface, b middle, c bottom water) in Lake Hongfeng reservoir, China, 2008-2014. Each datum represents the mean of six sample sites with standard errors). 
showed no significant differences with depth (mean values of $0.21,0.24$ and $0.31 \mathrm{mg} \mathrm{L}^{-1}$ in surface, mid-depths and bottom waters respectively) (Figs. 5b, 6c, 7b). There was a weak positive $\mathrm{NH}_{3}-\mathrm{H}$ correlation with cyanobacteria and Microcystis spp biomass in surface and mid-depth waters, but no correlation with bottom waters (Fig. 9).

\section{Phytoplankton community}

\section{Densities and cyanobacteria blooms 1980-2006}

Phytoplankton concentrations in Lake Hongfeng reservoir during 1980, 1987 and 1990 were low with a mean cell density of $2.1 \times 10^{6} \mathrm{~L}^{-1}$. In September 1994, a
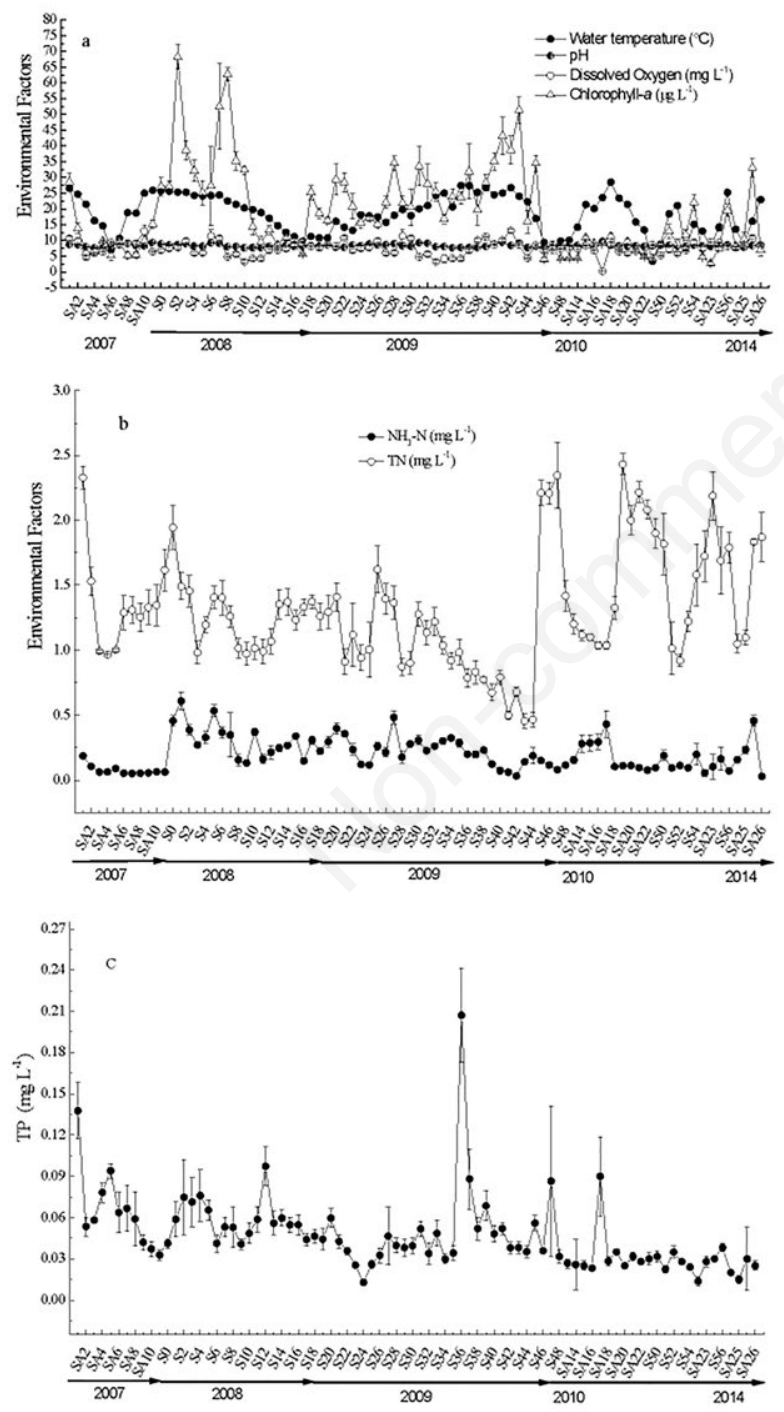

Fig. 5. Environmental Factors (a: water temperature, $\mathrm{pH}$, dissolved oxygen and chlorophyll- $a$; b: $\mathrm{NH}_{3}-\mathrm{N}, \mathrm{TN} ; \mathrm{c}$ : TP) for surface water in Lake Hongfeng reservoir, 2007-2014. Each datum represents the mean of six sample sites with standard errors). massive cyanobacteria bloom was recorded (Tab. 2). In the spring and summer of 1995, densities of A. flos-aquae and Microcystis spp were $>10^{8} \mathrm{~L}^{-1}$. Cyanobacteria blooms occurred every year (except 2000, no data) from 1997 to 2007. Changes in species and densities of other algae were relatively consistent (Tab. 2). Phytoplankton included Pyrrhophyta: Ceratium hirundinella (O.F.Müll.) Dujardin and Peridiniopsis; Cryptophyta: predominantly Cryptomonas erosa Ehrenb.; Bacillariophyta: mainly Cyclotella sensu lato and Synedra sensu lato; Chrysophyta: predominantly Dinobryon divergens O.E.Imhof; and Chlorophyta: mainly Pediastrum spp and Scenedesmus spp.

\section{Biomass of phytoplankton and Chlorophyll-a concentrations 2007-2014}

The end of 2007 (August-December) showed a decline from a late summer phytoplankton bloom to lower levels during the cooler season (Fig. 5). A pattern of cyanobacteria species succession was observed in Lake Hongfeng reservoir from August 2008-February 2014 (Fig. 3). Taxa changes included Microcystis spp, $P$.
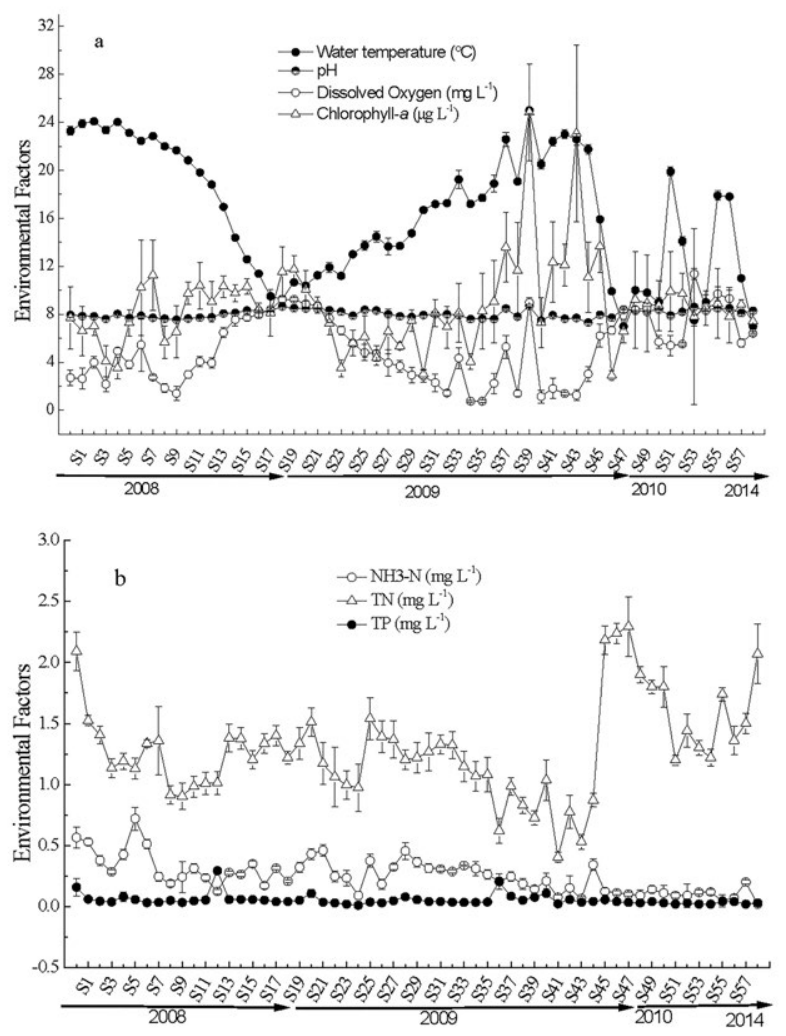

Fig. 6. Environmental Factors (a: water temperature, pH, dissolved oxygen and chlorophyll- $a$; $\left.\mathrm{b}: \mathrm{NH}_{3}-\mathrm{N}, \mathrm{TN}, \mathrm{TP}\right)$ for the mid-waters in Lake Hongfeng reservoir, 2008-2014. Each datum represents the mean of six sample sites with standard errors). 
limnetica, Anabaena spp (including Dolichospermum spp), A. flos-aquae, and Raphidiopsis spp.

In intensive monitoring (2008 - 2009), phytoplankton biomass fluctuated showing a seasonal occurrence of cyanobacterial blooms in Hongfeng Lake reservoir (Fig. 3). Cyanobacteria biomass during this period exceeded $2.0 \mathrm{mg} \mathrm{L}^{-1}$ at least $80 \%$ of the time. Total cyanobacteria biomass was correlated with total phytoplankton biomass $\left(R^{2=} 0.3, \mathrm{P}<0.05, \mathrm{n}=58\right)$ (Fig. $8 \mathrm{~b}$ ),

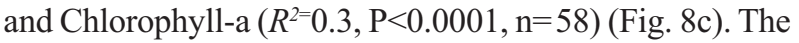
biomass of Microcystis spp contributed $57-100 \%$ to the total cyanobacterial biomass from July 2008 to January 2009, and May to August 2009. Aphanizomenon flos-aquae and Anabaena spp were prominent from February to April 2009. Pseudanabaena limnetica appeared in June 2009, and was the dominant species after January 2010 (Fig. 3a). At this time, phytoplankton biomass in mid-depth and bottom waters were significantly lower than in surface waters (Fig. 3b, c). Chlorophyll- $a$ concentrations were not correlated with the biomass of $P$. limnetica $(\mathrm{P}>0.05)$, even when densities were high.

Chlorophyta were represented by Scenedesmus spp, Tetraedron spp, Pediastrum spp, Ankistrodesmus spp, Spirogyra spp and Staurastrum spp. Chlorophytes contributed from $1.5-66 \%$ of the total biomass from 2008 to 2014 , with an average of $18 \%$. Chlorophyte biomass had a positive association with TN concentrations in middepth and bottom waters (Fig. 9 b,c). Diatom populations, were mainly composed of Aulacoseira spp, Synedra spp
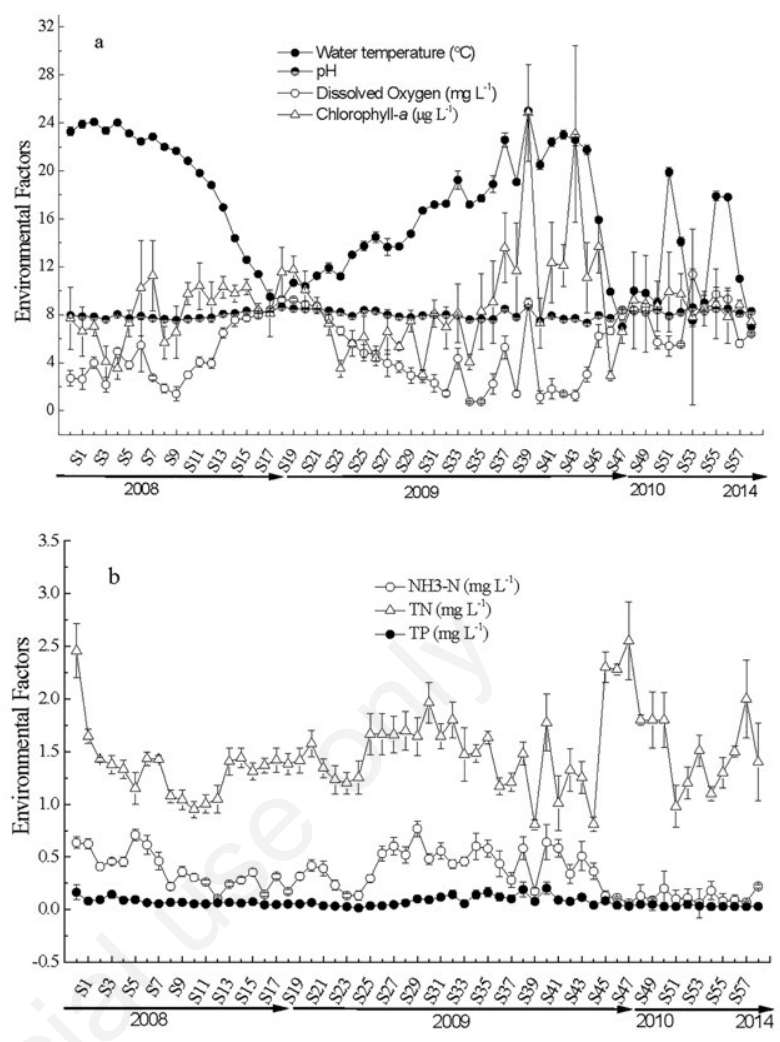

Fig. 7. Environmental Factors (a: water temperature, $\mathrm{pH}$, dissolved oxygen and chlorophyll- $a$; b: $\mathrm{NH}_{3}-\mathrm{N}, \mathrm{TN}, \mathrm{TP}$ ) for the bottom waters in Lake Hongfeng reservoir, 2008-2014. Each datum represents the mean of six sample sites with standard errors).

Tab. 2. Phytoplankton densities $\left(\mathrm{L}^{-1}\right)$ in Lake Hongfeng reservoir from 1980 to 2007.

\begin{tabular}{|c|c|c|c|c|c|c|}
\hline Sampling & \multicolumn{6}{|c|}{ Phytoplankton counts (with references) } \\
\hline May to Oct. 1980 & \multicolumn{6}{|c|}{ Total phytoplankton density <2.1 × $10^{6}$ (Shi and $\left.\mathrm{Wu}, 1982\right)$. } \\
\hline April 1987 & \multicolumn{6}{|c|}{ Total phytoplankton density $<10^{7} \mathrm{~L}^{-1}$ (Zhong and Shi, 1992) } \\
\hline July 990 & \multicolumn{6}{|c|}{ Total phytoplankton density $<10^{7} \mathrm{~L}^{-1}$ (Zhong and Shi, 1992) } \\
\hline Sept. to Oct. 1994 & \multicolumn{6}{|c|}{ Cyanobacteria blooms across lake; large number of fish killed (Pang and Pang, 2007) } \\
\hline Spring of 1995 & \multicolumn{6}{|c|}{ Total phytoplankton density $1.0793 \times 10^{8} \mathrm{~L}^{-1}($ Chen et al., 1998) } \\
\hline Summer of 1995 & \multicolumn{6}{|c|}{ Total phytoplankton density $5.8254 \times 10^{8} \mathrm{~L}^{-1}($ Chen et al., 1998$)$} \\
\hline September 1996 & \multicolumn{6}{|c|}{$22.97 \mathrm{mg} \mathrm{m}^{-3}$ (Pang and Pang, 2007) } \\
\hline Spring of 1997 & \multicolumn{6}{|c|}{ Aphanizomenon flos-aquae bloom. Average $9.332 \times 10^{7} \mathrm{~L}^{-1}$ (Chen et al., 2008) } \\
\hline March to April 1998 & \multicolumn{6}{|c|}{ Slurry of A. flos-aquae concentrated at $0.5 \mathrm{~m}$ near surface (Pang and Pang, 2007) } \\
\hline June $20^{\text {th }} 1999$ & \multicolumn{6}{|c|}{ Microcystis bloom (Pang and Pang, 2007) } \\
\hline 2000 & \multicolumn{6}{|c|}{ No reported the occurrence of algal bloom } \\
\hline 2001 to 2004 & \multicolumn{6}{|c|}{ Mean density $2.63 \times 10^{6}$ (Cyanobacteria bloom in local area) (Pang and Pang, 2007) } \\
\hline Sampling & Cyanophyta & Chlorophyta & Diatoms & Pyrrhophyta & Cryptophyta & Chrysophyta \\
\hline April 2005 & $7.2 \times 10^{6}$ & $2.15 \times 10^{6}$ & $0.65 \times 10^{6}$ & $0.016 \times 10^{6}$ & $0.79 \times 10^{6}$ & - \\
\hline August 2005 & $124.51 \times 10^{6}$ & $7.77 \times 10^{6}$ & $0.562 \times 10^{6}$ & - & $0.74 \times 10^{6}$ & - \\
\hline March 2006 & $29.69 \times 10^{6}$ & $7.13 \times 10^{6}$ & $1.49 \times 10^{6}$ & $0.011 \times 10^{6}$ & $0.15 \times 10^{6}$ & - \\
\hline August 2006 & $541 \times 10^{6}$ & $4.37 \times 10^{6}$ & $0.43 \times 10^{6}$ & - & $0.57 \times 10^{6}$ & - \\
\hline July 2007 & $149.6 \times 10^{6}$ & $4.84 \times 10^{6}$ & $0.858 \times 10^{6}$ & $0.044 \times 10^{6}$ & $0.506 \times 10^{6}$ & - \\
\hline
\end{tabular}

\footnotetext{
,- not detected.
} 
(sensu lato), Cyctotella spp (sensu lato), and Fragilaria spp (sensu lato). Diatoms contributed on average $17 \%$ to the total biomass from 2008-2014. Biomass of cryptophytes (mainly C. erosa) represented an average $5.8 \%$ of the total biomass from 2008 - 2014; there was a positive association between $\mathrm{pH}$ and biomass of cryptophytes in mid-depth waters (Fig. 9a). Pyrrhophyta biomass (predominantly Peridiniopsis spp and $C$. hirundinella) increased between 2010-2014 mainly because of minor increases in cell numbers and large cell biovolumes. Chrysophytes were rare in 2008-2013. Dinobyron divergens increased in 2014, and became the most prominent taxon; its biomass reaching $24.3 \mathrm{mg} \mathrm{L}^{-1}$ (Fig. 4a, right y-axis scale).

Biomass levels of Scenedesmus spp, Tetraedron spp, Pediastrum spp, Ankistrodesmus spp, Spirogyra spp, Staurastrum spp, Aulacoseira spp, Synedra spp, Cyctotella spp, Fragilaria spp, Pseudanabaena limnetica, C. erosa sensu lato, Peridiniopsis spp, C. hirundinella and $D$. divergens in mid-depth and bottom waters were
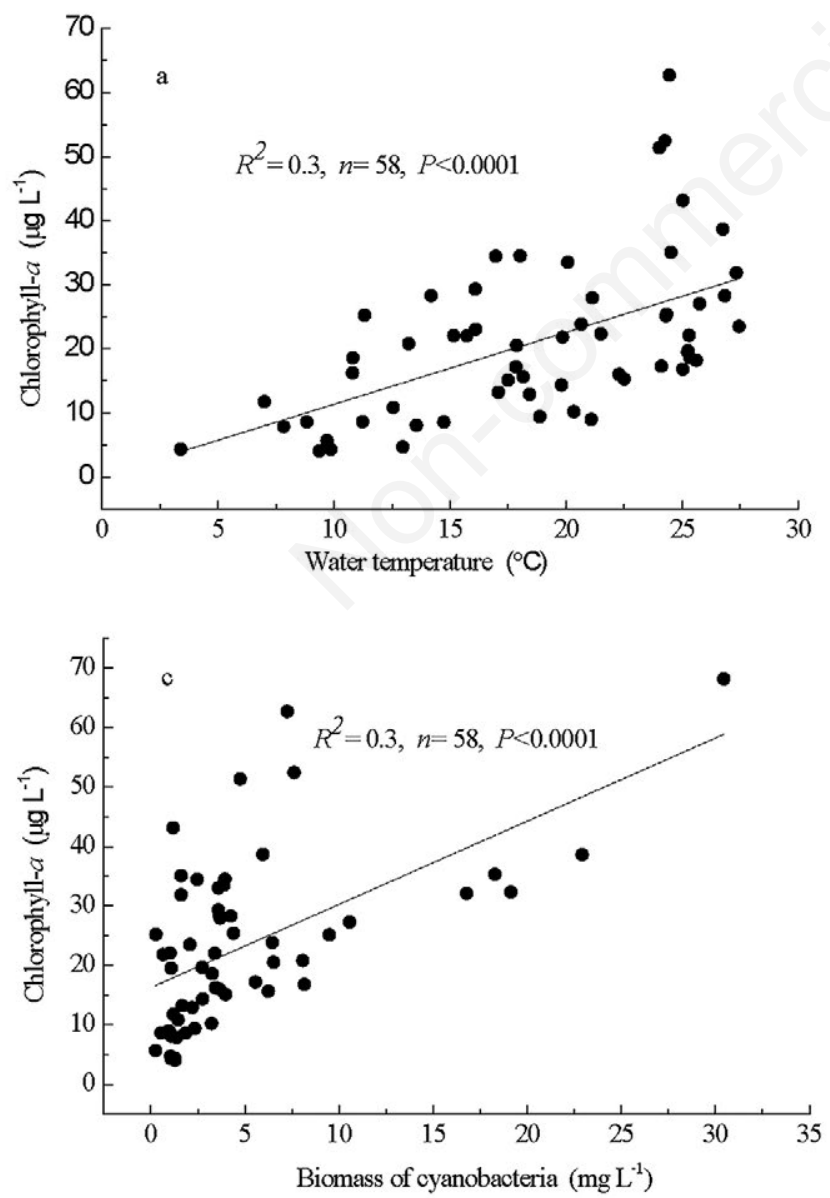

equivalent in proportions, but lower than surface waters. (Fig. 4 b,c).

\section{Light intensity and P. limnetica distribution}

The vertical distribution of $P$. limnetica and light were examined over two independent days, $8^{\text {th }}$ July 2012 and $8^{\text {th }}$ September 2012. In combination, light, temperature and nutrients showed that Zeu/Zmix was $<1.0$ which highlights the importance of light and temperature for phytoplankton growth (except to $P$. limnetica) (Figs. 4, 5, $6,10)$. Light levels from $0.5-12 \mathrm{~m}$ depths varied greatly, ranging from 0 to $265.6 \mu \mathrm{mol} \mathrm{m}{ }^{-2} \mathrm{~s}^{-1}$ over the two study dates (Fig. 10). The highest maximum illumination was at mid-day (Fig. 10 a,b). In July, light penetration extended down to $3.5 \mathrm{~m}$, whereas in September light penetration was down to $4 \mathrm{~m}$. At $6 \mathrm{~m}$ depth, light was low at all times representing $<1.3 \mu \mathrm{mol} \mathrm{m}{ }^{-2} \mathrm{~s}^{-1}$. At $12 \mathrm{~m}$ light availability was less than $0.1 \%\left(0.02 \mu \mathrm{mol} \mathrm{m}^{-2} \mathrm{~s}^{-1}\right)$ of ambient surface levels. Stratified sampling for $P$.
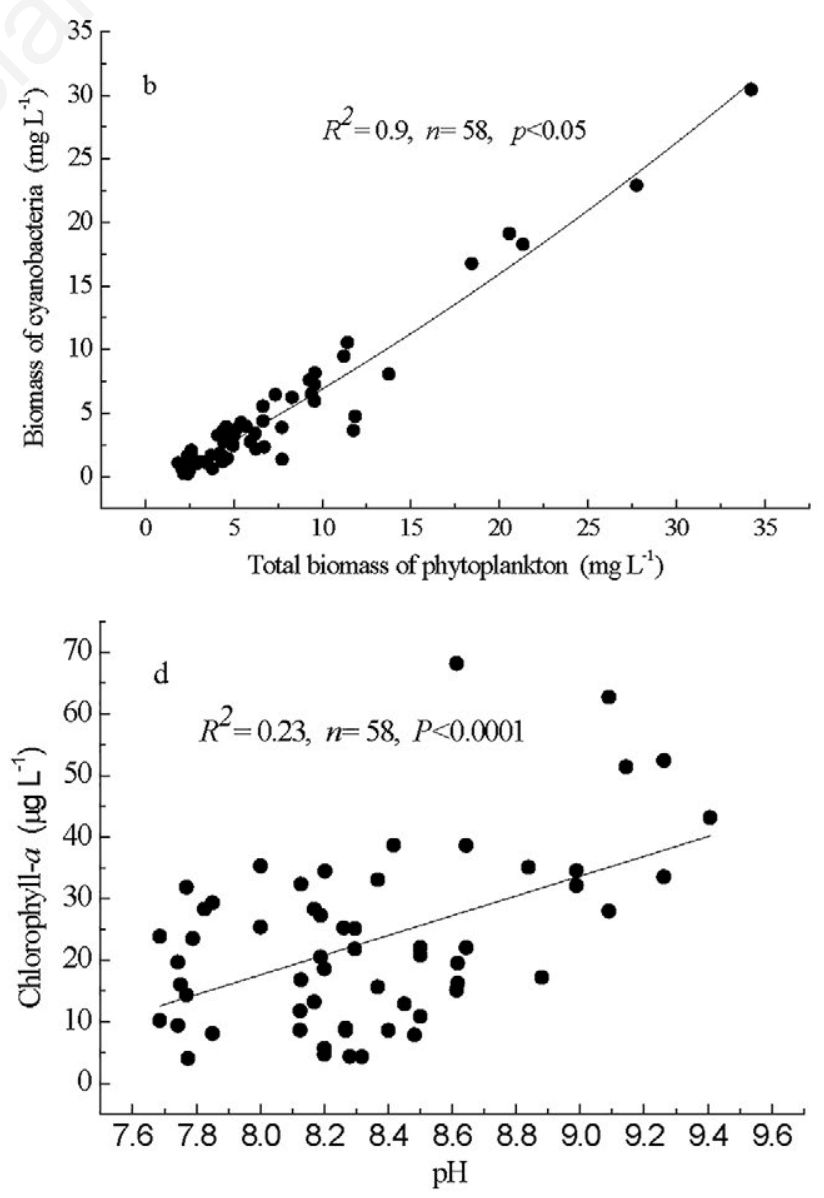

Fig. 8. Correlations between chlorophyll- $a$ and water temperature (a), biomass of cyanobacteria and phytoplankton (b), chlorophyll- $a$ and cyanobacteria (c), chlorophyll and $\mathrm{pH}(\mathrm{d})$. 

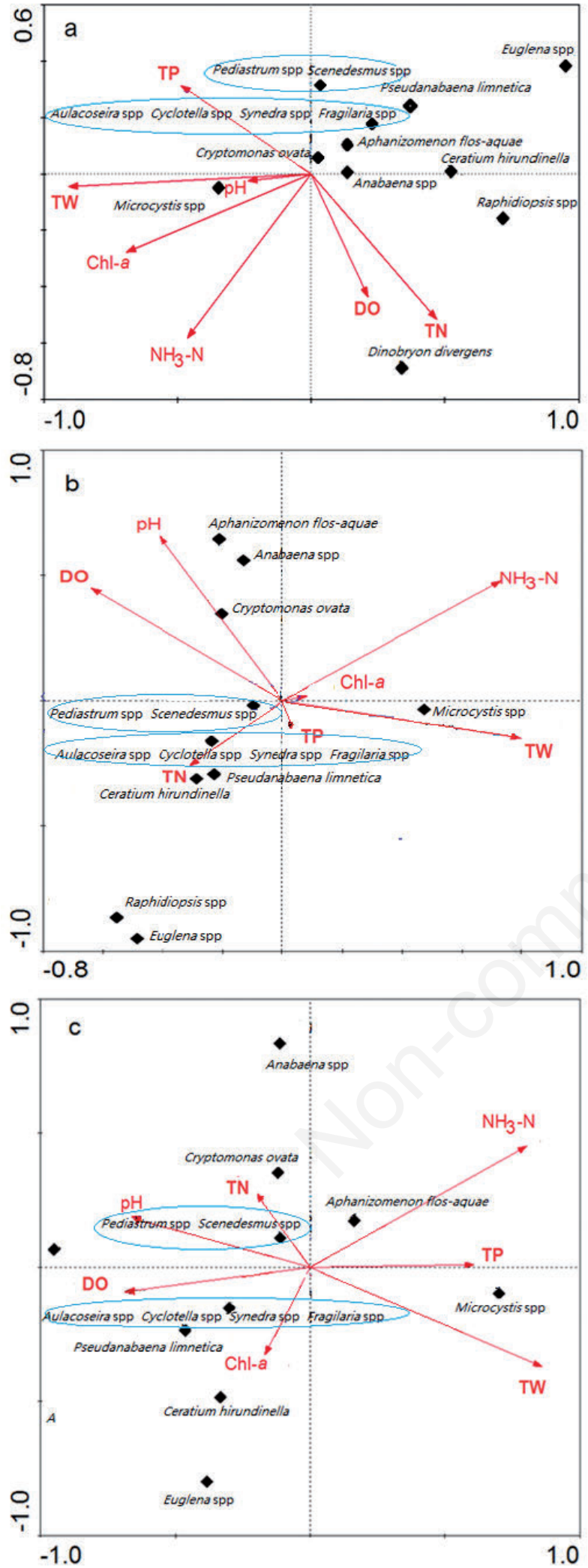

Fig. 9. CCA biplot representation of the impact of environmental factors and biomass on species from 2008 to 2014 using detrended canonical correspondence analysis (a: surface, b: middle, c: bottom). limnetica was conducted from 7:00-19:00 hrs on July $8^{\text {th }}$ and Sept. $8^{\text {th }}$ 2012. Throughout the day, P. limnetica numbers were consistent throughout the water column with densities $>10^{7} \mathrm{~L}^{-1}$ (Fig. 11). Vertical distributions of P. limnetica did not differ significantly from $0.5-10 \mathrm{~m}$ depths. Below $11 \mathrm{~m}$, which also coincides with light extinction, a significant decline in filament density was observed.

\section{DISCUSSION}

Changes in the phytoplankton community were studied to document cHABs and the recovery of Hongfeng Lake reservoir, after the introduction of fish farming and reservoir nutrification. Nine years after the termination of fish farming there was a shift in community structure away from cHABs to a more diverse algal community dominated by $P$. limnetica. Pseudanabaena spp do not dramatically affect water quality (Acinas et al., 2009), although the production of microcystin was
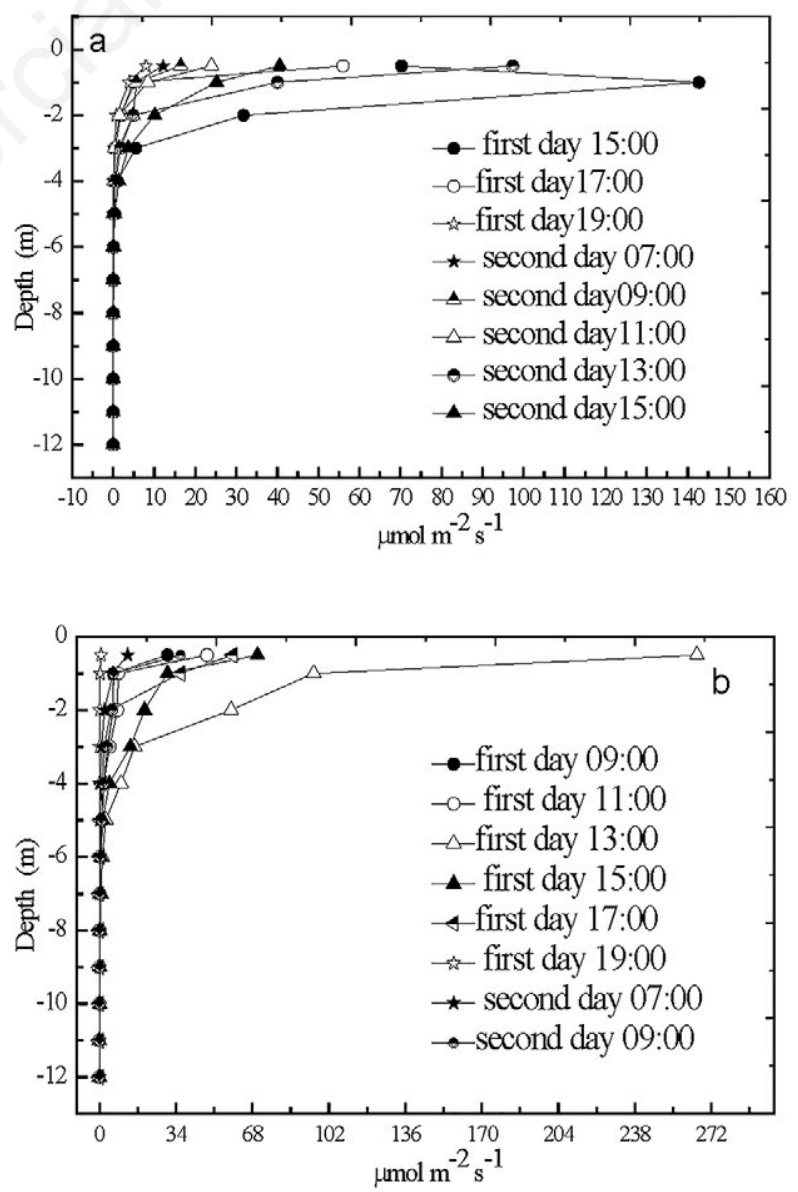

Fig. 10. Depth-time distribution of light at Site 6 in Lake Hongfeng in July (a) and September (b) 2012. 
reported at least once in natural populations (Maršálek et al., 2003). This community shift illustrates that when excess nutrients are eliminated from lake systems, natural species competition under varied environmental factors will favor a more diverse and healthier ecosystem.

Hongfeng Lake reservoir is an important water source for the City of Guiyang. Since 1996, this reservoir has been protected from excessive anthropogenic activities, although some industrial development and signs of disturbance impacts are evident. After 2008, there were 28 species of fish in Hongfeng Lake reservoir belonging to 4 orders and 6 families (Mou et al., 2012). One of the species (C. carpio), was cultured by in framing cages, and indirectly had a significant effect (nitrification) on the reservoir during fish farming (Long et al., 2013). Prior to 1994 (before fish farming), there was no evident topdown impact by the fish community on water quality (Shi, 1982). Since 2008 (after fish farming), the fish community has maintained populations around $51.610^{-3}$ ( $\mathrm{SD} \pm 36.5$ ) ind $\mathrm{m}^{-3}$ (Mou et al., 2012) and there was no
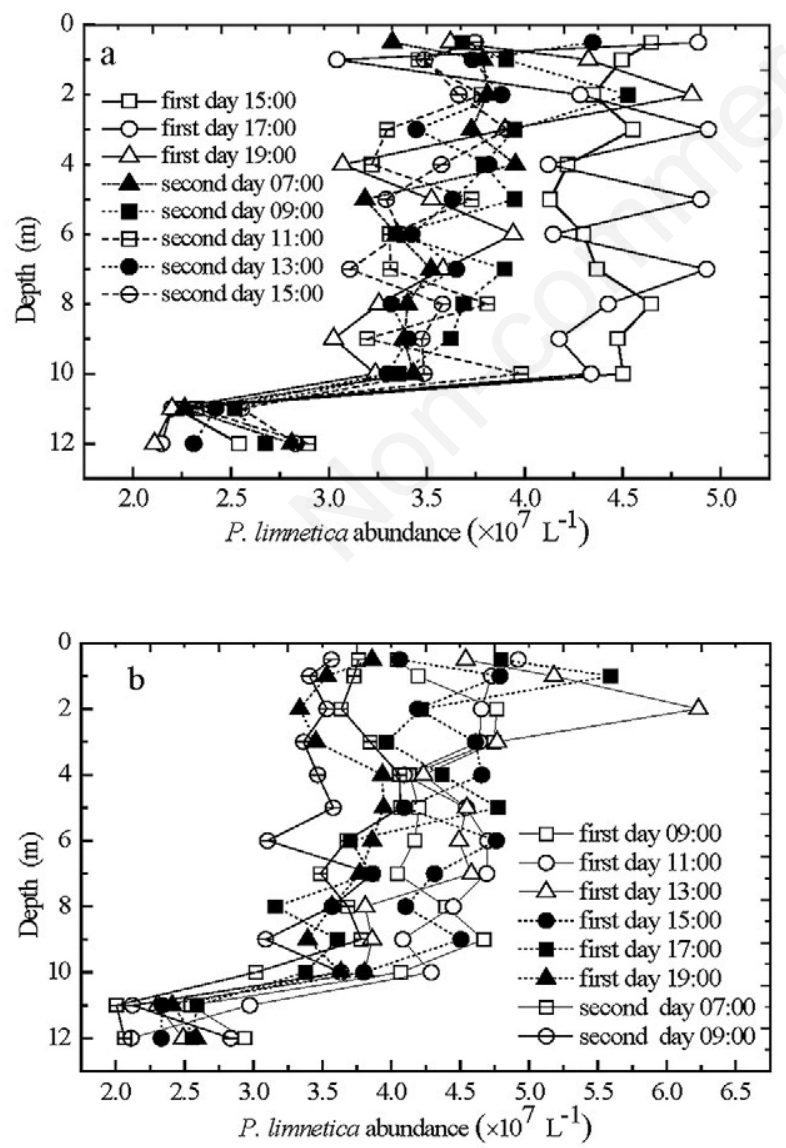

Fig. 11. Vertical profiles of P. limnetica in Lake Hongfeng Site 6 in July (a) and September (b) 2012. significant difference in the fish communities of 1981 and 2010 with the main species represented by $C$. carpio $(\mathrm{He}$ et al., 2010). At present, the fish standing stock is not high enough to have a significant top-down effect on the phytoplankton of a eutrophic/mesotrophic system.

Cyanobacteria blooms (cHABs) appeared during and after the fish farming from 1995 - 2007. The yearly blooms in 2008 - 2009 followed a dominant succession of species starting with Microcystis spp and P. limnetica (summer) followed by $A$. flos-aquae (winter/spring). Cyanobacteria densities reached $>10^{8} \mathrm{~L}^{-1}$ for both Microcystis spp and A. flos-aquae which was significantly higher than total phytoplankton densities of $>10^{6} \mathrm{~L}^{-1}$ observed prior to the blooms (1980-1994) (Chen et al., 1998; Zhong and Shi, 1992). Biomass trends in 2008 2009 followed cell densities with Microcystis blooms in the summer (July-September) and A. flos-aquae blooms in February-April. High TN (mean $4.9 \mathrm{mg} \mathrm{L}^{-1}$ ) and TP (mean $0.07 \mathrm{mg} \mathrm{L}^{-1}$ ) concentrations during and after fish farming, attributed to undigested and wasted feedstock, were the primary factors for the cHABs after 1994 (Liang et al., 1998; 1999; 2003). There was no significant relationship between TN:TP ratios and cyanobacterial blooms, although some importance in the combined effect of these nutrients could be seen for Microcystis spp. This has also been reported by other authors (Pick, 2016 and references within). With lower nutrient loads (TP $<0.04$ $\mathrm{mg} \mathrm{L}^{-1} ; \mathrm{TN}<1.8 \mathrm{mg} \mathrm{L}^{-1}$ ) after 2010, competitive species shifts to $P$. limnetica occurred along with other taxa from the diatom, chlorophyte, chrysophyte and cryptophyte communities. This shift was linked to a number of factors including light, temperature and nutrients.

\section{Water temperature, light and pH}

There is clearly a temporal discontinuity between different cyanobacteria species and cHABs. In this study water temperatures up to $28^{\circ} \mathrm{C}$ were important for Microcystis spp growth. Other studies have also shown that water temperature had an impact on cHABs (Ma et al., 2015). Nalewajko and Murphy (2001) noted that harmful cyanobacteria tolerate higher temperatures relative to other algae, while Okino (1973) commented that in several Japanese lakes Microcystis spp did not appear (germinate and develop) until the water temperature was $>20^{\circ} \mathrm{C}$. Thomas and Walsby (1986) suggested that declining temperature might in some way be affecting the buoyancy of colonies, which could affect the growth rate of Microcystis spp. Further Kruger and Eloff (1978) found a sharp decline in the growth rate of Microcystis spp below $15^{\circ} \mathrm{C}$, while Robarts and Zohary (1987) reported that water temperature for the optimum growth of Microcystis spp was between $25-30.5^{\circ} \mathrm{C}$. In this study, we found that the biomass of Microcystis spp was positively associated with water temperature up to $28^{\circ} \mathrm{C}$ 
(Fig. 9). When the surface water temperature of Hongfeng Lake reservoir was $>20^{\circ} \mathrm{C}$ the biomass of Microcystis spp was $>3.0 \mathrm{mg} \mathrm{L}^{-1}$, and Chlorophyll- $a$ exceeded $20 \mathrm{~g} \mathrm{~L}^{-1}$, which shows the significant of surface water temperature on growth, when nutrient conditions are optimized. In contrast, the biomass of $A$. flos-aquae was optimized with water temperatures $<20^{\circ} \mathrm{C}$. Other studies suggest that persistent blooms of A. flos-aquae and Anabaena spp can occur between $15-20^{\circ} \mathrm{C}$, while Microcystis spp cannot grow well at water temperatures $<15^{\circ} \mathrm{C}$ (Robarts and Zohary, 1987). Water temperature was a controlling factor in the succession of A. flos-aquae and Microcystis spp blooms in Lake Hongfeng during the spring and summer season of 2008-2009 (Fig. 8).

Light is a limiting factor (Zeu/Zmix <10.0) in Hongfeng lake reservoir. Phytoplankton biomass in Hongfeng lake reservoir decreases with declining light levels and water depth. However, after 2010, in day experiments the vertical distribution of $P$. limnetica was not significantly difference from $0.5-10 \mathrm{~m}$, with consistent densities $>10^{7} \mathrm{~L}^{-1}$ and biomass $\left(>0.198 \mathrm{mg} \mathrm{L}^{-1}\right)$. In addition, the biomass of $P$. limnetica was also not significantly different in surface, and mid-depth waters from 2010 - 2014 with no correlation between light intensity and vertical distributions. Pseudanabaena spp have higher levels of phycocyanin which can absorb light for growth at deeper water depths (Acinas et al., 2009). Light throughout the water column had little impact on the growth of $P$. limnetica and this in part explains the prominence of $P$. limnetica when optimal bloom conditions were not present for Microcystis spp and A. flos-aquae. Pseudanabaena limnetica had a competitive advantage with a wider tolerance of light changes when nutrients were lower.

Phytoplankton photosynthesis removes $\mathrm{CO}_{2}$ from the aquatic environment which can result in a rise of $\mathrm{pH}$ (Qui and Gao, 2002). Several studies have reported higher $\mathrm{pH}$ conditions caused by cyanobacteria growth (Oliver and Ganf, 2000; O'Neil et al., 2012; Qui and Gao, 2002). To support this, Laamanen et al. (2002) and $\mathrm{Hu}$ (2011) reported that A. flos-aquae and Microcystis spp bloom were significantly correlated with high $\mathrm{pH} 9-11$. The present study found higher $\mathrm{pH}$ values in surface waters were positively correlated with higher productivity (biomass and chlorophyll- $a$ ), although the relationship was not linear (Fig. 8d). This was evident with cyanobacteria blooms of Microcystis spp in July 20082009 , growing at $\mathrm{pH}>8.5$. However, there was no correlation between $\mathrm{pH}$ and biomass of cyanobacteria in mid-depth and bottom waters suggesting that cyanobacterial blooms in the surface waters of the reservoir were not affecting $\mathrm{pH}$ levels in lower waters of the reservoir. Other algae, specifically chlorophytes and cryptophytes were not linked to $\mathrm{pH}$.

\section{Nutrients impacts on phytoplankton biomass}

Relationships of cyanobacteria growth with nitrogen and phosphorus are still a hotspot of uncertainty in the scientific literature (Anderson et al., 2002; Pick, 2016), because $\mathrm{N}$ and $\mathrm{P}$ are essential elements for phytoplankton growth (Conley et al., 2009). Some studies have shown TP concentration below $0.01 \mathrm{mg} \mathrm{L}^{-1}$, will limit the size of phytoplankton to $<35-50 \mu \mathrm{m}$, while TP concentrations $>0.05 \mathrm{mg} \mathrm{L}^{-1}$, will encourage the dominance of larger phytoplankton species (Watson et al., 1992). In our study, TP concentrations averaged $0.055 \mathrm{mg} \mathrm{L}^{-1}$ from 20072009, with large taxa becoming smaller after 2009 under lower TP concentrations. TN was also significantly reduced after 2010 and correlated well with the community shift.

Under fish farming, the dominant phytoplankton were colonial Microcystis spp, A. flos-aquae and Anabaena spp. After 2009, when TP levels were significantly lower $\left(<0.04 \mathrm{mg} \mathrm{L}^{-1}\right)$, phytoplankton species with smaller filament sizes and biovolumes (like $P$. limnetica) dominated. Likewise, diatoms with smaller sizes and biovolumes were prominent species from January 20102014. In this study, CCA results support the observation that eutrophication processes favored larger cyanobacteria taxa. Under lower nutrient conditions, small taxa with lower nutrient requirements and taxa with broader niches (population reserves) were better able to compete. Higher densities and biomass of P. limnetica, and diatoms in Hongfeng Lake reservoir further sequestered TP from the soluble phosphorus fraction, which reduced the availability of soluble $\mathrm{P}$ for the reintroduction and bloom formation of larger taxa. Xu et al. (2010) also reported that Microcystis spp blooms were limited by lower phosphorus concentration in Lake Taihu. We also found that a lower TP concentration $\left(0.02 \mathrm{mg} \mathrm{L}^{-1}\right)$ in Apr. 2014, enhanced the growth and biomass of Dinobyron divergens (24.3 $\mathrm{mg} \mathrm{L} \mathrm{L}^{-1}$ ). The development of competitive succession over the last seven years from cyanobacterial blooms to mixed cyanobacteria with diatoms and chrysophytes ( $D$. divergens) suggests that recovery to prefisheries water quality is developing. However, a steady state is not present and the very recent re-occurrence of Microcystis spp $\left(0.011 \mathrm{mg} \mathrm{L}^{-1}\right)$ in higher numbers illustrates the biological instability of the reservoir. Inorganic nitrogen was another key factor for phytoplankton development. Previous studies suggest that moderate levels (0.3-0.8 $\left.\mathrm{mg} \mathrm{L}^{-1}\right)$ of inorganic nitrogen are required for the growth and reproduction of Microcystis spp (Ma et al., 2015). In this study $\mathrm{NH}_{3}-\mathrm{N}$ was positively associated with Microcystis growth throughout the water column.

The reduced periodicity of TN may have been the factor that triggered the transform of phytoplankton composition during June to September 2009 (Fig. 5a). In 
contrast, the increase in TN after 2009 with seasonal fluctuations may have induced the growth of $P$. limnetica (a poor nitrogen fixer). In the later scenario, higher TN (1.0-2.3 $\mathrm{mg} \mathrm{L}^{-1}$ ) and low TP conditions (ca. $0.03 \mathrm{mg} \mathrm{L}^{-1}$ ) will in part determine the phytoplankton community structure after $\mathrm{cHAB}$ events.

Other studies have attributed different factors to the collapse of cHABs. A. flos-aquae blooms were affected by photo-oxidation, $\mathrm{O}_{2}$ toxicity, and viruses (Coulombe and Robinson, 2011). In this study, nutrients, light, temperature, and other algae were studied. It could be that other parameters not studied could have more of an effect on biological process and biota. Viruses and $\mathrm{O}_{2}$ toxicity are interesting factors but to date they have not been routinely observed in $\mathrm{cHAB}$ cultures and/or culture experiments. In the future, eDNA studies might help resolve the potential impacts of other less obvious biological factors. Enhanced nutrients induced the development of cHABs in Hongfeng lake reservoir. Once introduced, other factors (e.g., light, temperature) played a role after nutrient reductions, in the alterations of blooms through species community shifts under changing optimum conditions.

\section{Global implications}

Anthropogenic and natural trophic factors are important in the stability of the pelagic community. It is well documented that anthropogenic impacts from reservoir development cause cHABs (Pick and references within, 2016). Higher temperatures, nutrients (TN, TP) and reasonable light will favor the development of cHABs like Microcystis spp. With the control of nutrient loads a community shift away from cHABs can occur. In this study a decline in nutrients, with a drop in TP relative to TN, favored a shift from Microcystis summer blooms to $P$. limnetica and other algae like Aulacoseira spp, Synedra spp, Cyctotella spp (sensu lato) and Fragilaria spp (sensu lato). In Hongfeng reservoir $P$. limnetica can out-compete Microcystis spp when temperatures are $<20^{\circ} \mathrm{C}$ and TP is $<0.03 \mathrm{mg} \mathrm{L}^{-1}$. Although only a selected number of environmental variables were examined, the CCA analysis over 7 years supports observations that temperature and nutrients were associated with the species shifts. Therefore, the replacement of cHABs with less toxic cyanobacteria creates a potentially interesting scenario (new community condition) for reservoir water quality management and the removal of harmful cyanobacteria. Pseudanabaena limnetica is a filamentous, nonheterocystous freshwater cyanobacterium (Alvensleben et al., 2013) with only one tentative report of toxin production (Marsálek et al., 2003). Thus, the new community condition with $P$. limnetica is less problematic compared to cHABs with Microcystis and Aphanizomenon blooms.

Planned increases in dam building around the world over the next 50 years will have significant environmental consequences (Ansar et al., 2014). Increased evaporation, sedimentation and nutrient loading in constructed reservoirs and impoundment lakes will change water quality and ecosystem stability across ecoregions (Maavara et al., 2015). Further, many of the planned dams are located in regions which already have poor water quality or ecosystem resilience (Stone, 2011; Ziv et al., 2012). The occurrences of cHABs, in reservoirs and impoundments, will increase into the next century with yet further unknown economic and environmental implications. In addition, the increased frequency of extreme events like droughts and flooding will also impact phytoplankton communities with potential temporal and spatial increases in cHABs. The management of harmful cyanobacterial will be an important component of our future water footprint.

\section{CONCLUSIONS}

Over the last 22 years significant phytoplankton changes in Hongfeng lake reservoir have been observed with multiple years of cHABs. Data collected over these years have helped unravel the transition of growth from a low productive lake/reservoir to one with repetitive bloom events. With the introduction of fish farming and other anthropogenic activities, the reservoir went into ultraeutrophic primary production with repeated cHAB events. After the cessation of fish farming there has been a slow recovery of the reservoir in both algal productivity and nutrient loading. A conversion from problematic species (Microcystis spp, A. flos-aquae) to the less problematic species $P$. limnetica and other associated non-cyanobacteria taxa (e.g., D. divergens) was observed after 2010. $P$ seudanabaena limnetica is potential a nuisance taxon but with a lower cHABs concern. Based on current fish populations estimates, a top-down impact on the food web is not evident. Thus, trophic factors (bottom-up) were examined, and correlations between cHABs and selected environmental variables were observed. The paradox of the plankton blooms can be explained by varying chemical factors, physical factors (light, and temperature) and species competitive succession. Higher temperatures, nutrients (TN, TP) and reasonable light favored the development of Microcystis spp blooms, which occurred after anthropogenic manipulations of the reservoir. Microcystis blooms under these conditions have been reported globally (Pick and references within, 2016). With the control of nutrient loads, a decline in TP relative to TN favored a shift from Microcystis summer blooms to the growth of $P$. limnetica with other algae like Aulacoseira spp, Synedra spp, Cyctotella spp (sensu lato) and Fragilaria spp (sensu lato). In Hongfeng reservoir $P$. limnetica, a light tolerant species, can out-compete Microcystis spp when 
temperatures are $<20^{\circ} \mathrm{C}$ and TP is $<0.03 \mathrm{mg} \mathrm{L}^{-1}$. The apparent competitive advantage of $P$. limnetica and other algae (e.g., Aulacoseira spp, Synedra spp, Cyctotella spp, Fragilaria spp) are enhanced by their distribution throughout the epilimnion. Pseudanabaena limnetica is a filamentous, nonheterocystous freshwater cyanobacterium which is not as problematic as Microcystis and Aphanizomenon species. In Hongfeng lake reservoir, the initial introduction of nauseous Microcystis and Aphanizomenon blooms was directly related to nutrient loading, while the continued reoccurrence of these species appears to be associated with cyst availability, temperature, growing season and biotic competition. Although only a selected number of environmental variables were examined, the CCA analysis over seven years supports observations that temperature, and nutrients were associated with biological competition and species shifts. The replacement of cHABs with the growth of less toxic cyanobacteria like $P$. limnetica, and other algae creates a potentially interesting scenario (new community condition) for the removal of problematic taxa.

\section{ACKNOWLEDGMENTS}

This work was supported by the Research Project of Social Development of Guiyang City (2008 No. 5-3 and 2011 No. 59), and by the National Natural Science Foundation of China-Guangdong United Foundation (U1501235). Additional support for this research was supplied through a RAC grant to PBH from the Canadian Museum of Nature.

\section{REFERENCES}

Acinas SG, Haverkamp THA, Huisman J, Stal LJ, 2009. Phenotypic and genetic diversification of Pseudanabaena spp (Cyanobacteria). Isme J. 3:31-46.

Alvensleben NV, Stookey K, Magnusson M, Heimann K, 2013. Salinity tolerance of Picochlorum atomus and the use of salinity for contamination control by the freshwater cyanobacterium Pseudanabaena limnetica. PloS One 1-12.

Anderson DM, Gilbert PM, Burkholder JM, 2002. Harmful algal blooms and eutrophication: nutrient sources, composition and consequences. Estuaries 25:704-726.

Ansar A, Flyvbjerg B, Budzier A, Lunn D, 2014. Should we build more large dams? The actual costs of hydropower megaproject development. Energ. Policy 69:43-56.

Australian and New Zealand Environment and Conservation Council, 1992. Australian water quality guidelines for fresh and marine waters, National water quality management strategy. Australian and New Zealand Environment and Conservation Council.

Bláha L, Babica P, Maršálek B, 2009. Toxins produced in cyanobacterial water blooms-toxicity and risks. Toxicology 2:36-41.
Birks HJB, Juggins S, Line JM, 1990. Lake surface water chemistry reconstructions from paleolimnological data, p. 31-311. In: B.J. Mason (ed.), The surface water acidification programme. Cambridge University Press, Cambridge.

Conley JD, Paerl HW, Howarth RW, Boesch DF, Seitzinger SP, Havens KE, Lancelot C, Likens GE, 2009. Controlling eutrophication: nitrogen and phosphorus. Science 323:10141015.

Coulombe AM, Robinson GGC, 2011. Collapsing Aphanizomenon flos-aquae blooms: possible contributions of photo-oxidation, $\mathrm{O} 2$ toxicity, and cyanophages. Can. J. Bot. 59:1277-1284.

Chen C, Hu XH, Liu MS, Yi J, Pan H, 1998. A preliminary study on the distribution of phytoplankton and water pollution in Lake Hongfeng, China. J. Guizhou Normal Univ. 16:5-10.

Chen ZZ, Chen C, Yan N, Liu HM, Li Jie, 2008. Ecological changes of phytoplankton (1980-2006) in Lakes Hongfeng and the study of eutrophical trend. J. Guizhou Normal Univ. 25:5-10.

Fang ZQ, Li CX, 2009. Sediment deposition and its nutrient volume in Baihua Lake and Aha Lake. J. Guizhou Normal Univ. 27:30-33.

Francis G, 1878. Poisonous Australian Lake. Nature 18:11-12.

Hallegraeff GM, 1993. A review of harmful algal blooms and their apparent global increase. Phycologia 32:79-99.

Heisler JP, Gilbert J, Burkholder J, Anderson D, Cochlan W, Dennison W, Dortch Q, Gobler CJ, Heil C, Humphries E, Lewitus A, Magnien R, Marsall HG, Sellner K, Stockwell DA, Stoecker DK, Suddleson M, 2008. Eutrophication and harmful algal blooms: a scientific consensus. Harmful Algae 8:3-13.

Hillebrand H, Dürselen C-D, Kirschtel D, Pollingher U, Zohary T, 1999. Biovolume calculation for pelagic and benthic microalgae J. Phycol. 35:403-424.

Hoagland P, Scatasta S, 2006. The Economic Effects of Harmful Algal Blooms. Ecol. Harmful Algae 619: 391-402.

Hu HJ, Li Y, Zhu J, 1980. [Freshwater algae in China].[Book in Chinese]. Shanghai Science and Technology Press, Shanghai.

$\mathrm{Hu} \mathrm{HJ}, 2011$. [The biology of water-blooms blue-green algae].[Book in Chinese]. Science Press, Beijing.

He TR, Wu YY, Pan LS, Feng XB, 2010. Distribution of Mercury species and their concentrations in fish in Hongfeng Reservoir. J. Southw. Univ. 32:78-82.

Jonas A, Sholz S, Fetter E, Sychrova E, Novakova K, 2014. Endocrine, teratogenic and neurotoxic effects of cyanobacteria detected by cellularin vitro and zebrafish embryos assays. Chemosphere 120:321-327.

Knoll LB, Sarnelle O, Hamilton SK, Kissman CEH, Wilson AE, Rose JB, Morgan MR, 2008. Invasive zebra mussels (Dreissena polymorpha) increase cyanobacterial toxin concentrations in low-nutrient lakes. Can. J. Fish. Aquat. Sci. 65:448-455.

Kruger GHJ, Eloff JN, 1978. The effect of temperature on specific growth rate and activation energy of Microcystis and Synechococcus isolates relevant to the onset of natural blooms. J. Limnol. Soc. S. Africa 4:9-20.

Laamanen MJ, Forsstrom L, Sivonen K, 2002. Diversity of Aphanizomenon flos-aquae (cyanobacterium) populations along a Baltic Sea salinity gradient. Appl. Environ. Microb. 68:5296-5303. 
Liang X, Xie P, Li S, Tang H, Liu H, 2003. The low TN:TP ratio, a cause or a result of Microcystis blooms. Water Res. 37:2073-2080.

Liang XJ, Fu WJ, Zhang MS, Wang AM, 1998. Investigation on nutrient and organic pollutants of Lake Baihua and Hongfeng,China. Guizhou Sci. 16:311-315.

Liang XJ, Zhang MS, Wang AM, Fu WJ, 1999. Investigation on headwaters, sources of pollution, main nutrient elements and pollutants of Lake Hongfeng and Baihua, China. J. Guizhou Norm Univ. 17:37-39.

Li Q, 2001. Analysis of recent eutrophication status of Lakes Hongfeng and Baihua, China. J Guizhou Univ Techn. 30:98102.

Li, Y, Zhang JY, Ni L, Huang SQ, Wang J, Yang L, Lei H, 2013. Characteristics of weather of summer rainstorm from 1961 to 2010 in Guizyou City. Guizhou Province Meteorological Society.

Liao GH, Zhong X, Pang ZQ, 2004. Analysis of water pollution trend and control measures in Both Lake Hongfeng and Baihua, China. Earth Environ. 32:49-52.

Liu B, Yan HY, Wang CP, Li QH, Stephane G, Jorge ES, Feng $\mathrm{XB}$, Janusz D, 2012. Insights into low fish mercury bioaccumulation in a mercury-contaminated reservoir, Guizhou, China. Environ. Pollut. 160:109-117.

Long SX, Chen C, Guo Y, Yan N, Yu ZX, 2013. Phytoplankton's characteristics of community structure and eutrophication in Lake Hongfeng, China. Environ. Monitor. China 29:2329.

Lewitus AJ, Horner RA, Caron D, Mendoza EG, Hickey BM, 2012. Harmful algal blooms along the North American west coast region: History, trends, causes, and impacts. Harmful Algae 19:133-159.

Lu YC, Liu CQ, Wang SL, Xu G, Liu F, 2007. Seasonal variability of $\mathrm{p}(\mathrm{CO} 2)$ in the two karst Reservoirs, Hongfeng and Baihua Lakes in Guizhou Province, China. Environ Sci. 28:2674-2681.

Ma JR, Brookes JD, Qin BQ, Paerl HW, Gao G, Wu P, 2014. Environmental factors controlling colony formation in blooms of the cyanobacteria Microcystis spp in Lake Taihu, China. Harmful Algae 31:136-142.

Ma JR, Qin Bq, Paerl HW, Brookes JD, Wu P, Zhou J, Deng JM, Guo JS, Li Z, 2015. Green algal over cyanobacterial dominance promote with nitrogen and phosphorus additions in a mesocosm study at Lake Taihu, China. Environ. Sci. Pollut. Res. 22:5041-5049.

Ma JR, Deng JM, Qin BQ, Long SX, 2013. Progress and prospects on cyanobacteria bloom-forming mechanism in lakes. Acta Ecol. Sinica 33:3020-3030.

Maavara T, Parons CT, Ridenour C, Stojanovic S, Durr HH, Powley HR, Van Cappelein P, 2015. Global phosphorus retention by river damming. P. Natl. Acad. Sci. USA 112:15603-15608.

Maršálek B, Blaha L, Babica P, 2003. Analyses of microcystins in the biomass of Pseudanabaena limnetica collected in Znojmo reservoir. Czech Phycology, Olomouc 3: 195-197.

Mou H, Yao J, Ni C, Fang GZ, An M, Ma S, 1012. Hydroacoustic survey of fish resource and spatial distribution in Hongfeng Lake. South China Fish. Sci. 8:62-69.

Nalewajko C, Murphy TP, 2001. Effects of temperature, and availability of nitrogen and phosphorus on the abundance of
Anabaena and Microcystis in Lake Biwa, Japan: an experimental approach. Limnology 2:45-48.

Oliver RL, Ganf GG, 2000. Freshwater blooms, p. 149-194. In: B.S. Whitton and M. Potts (eds.), Ecology of cyanobacteria, their diversity in time and space. Kluwer Academic, Dordrecht.

O’Neil JM, Davis TW, Burford MA, Gobler CJ, 2012. The rise of harmful cyanobacteria blooms: The potential roles of eutrophication and climate change. Harmful Algae 14:313334.

Okino T, 1973. Studies on the blooming of Microcystis aeruginosa. Jap. J. Bot. 20:381-402.

Pang L, Pang ZQ, 2007. Investigation event of pollution on Lake Hongfeng and Baihua, China. Protect Environ. Technol. 3:44-48.

Paerl HW, Huisman J, 2009. Climate change: a catalyst for global expansion of harmful cyanobacterial blooms. Environ. Microbiol. Rep. 1:27-37.

Papista E, Acs E, Boddi B, 2002.Chlorophyll-a determination with etanol-a critical test. Hydrobiologia 1:191-198.

Pick FR, 2016. Blooming algae: a Canadian perspective on the rise of toxic cyanobacteria. Can. J. Fish. Aquat. Sci. 73:1149-1158.

Proulx M, Pick FR, Mazumder A, Hamilton PB, Lean DRS, 1996. Effects of nutrients and planktivorous fish on the phytoplankton of shallow and deep aquatic systems. Ecology 77:1556-1572.

Qui B, Gao K, 2002. Effects of $\mathrm{CO}_{2}$ enrichment on the bloomforming cyanobacterium Microcystis aeruginosa (Cyanophyceae): physiological responses and relationships with the availability of dissolved inorganic carbon. J. Phycol. 38:721-729.

Reynolds CS, Walsby AE, 1975. Water blooms. Biol. Rev. 50:437-481.

Robarts RD, Zohary T, 1987. Temperature effects on photosynthetic capacity, respiration and growth rates of bloom-forming cyanobacteria. New Zeal. J. Mar. Fresh. 21:391-399.

Shen DJ, Zhang MH, Liu Y, Peng ZS, Ye XY, Zhang JJ, Cheng $\mathrm{G}, 2006$. Analysis of actuality rich nourish mention on Hongfeng Lake reservoir, China. J. Guizhou Univ. 23:175179.

Shi SF, Wu BS, 1982. Phytoplankton of Lake Hongfeng and Baihua. Guizhou Agr. Sci. 4:62-63.

Shi SF, 1982. Community of fish in Lake Hongfeng. Guizhou Agr. Sci. 3:44-50.

Stone R, 2011. Hydropower. The legacy of the Three Gorges Dam. Science 333:817.

Thomas RH, Walsby AE, 1986. The effect of temperature on recovery of buoyancy by Microcystis. Microbiology 132:1665-1672.

Ter Braak CJF, Prentice IC, 1988. A theory of gradient analysis. Adv. Ecol. Res. 18:221-317.

Watson S, McCauley E, Downing JA, 1992. Sigmoid relationships between phosphorus, algal biomass, and algal community structure. Can. J. Fish. Aquat. Sci. 49:26052610.

Wu YY, Li PP, Wang PL, Liu CQ, He M, Chen C, 2004. Changes of the water quality and phytoplankton in Lake Hongfeng and Baihua, China. J. Agro-environ. Sci. 23:745-747. 
Wu Z, He Y, Yan XD, Zhang JY, 2014. Characteristics of the climate change in Guiyang dryness and wetness and rainfall trends in summer. J. Guizhou Norm. University (Natural Sciences) 32(6): 30-34.

Wiegand GC, Pflugmacher S, 2005. Ecotoxicological effects of selected cyanobacterial secondary metabolites: a short review. Toxicol. Appl. Pharm. 203:201-218.

Xu H, Paerl HW, Qin B, Zhu G, Gao G, 2010. Nitrogen and phosphorus inputs control phytoplankton growth in eutrophic Lake Taihu, China. Limnol. Oceanogr. 55:420-432.

Zhong X, Liao GH, Sun W, 2004. Effect of cage -culture fishing on the water quality of lakes and reservoirs and protection for water source. J. Guizhou Norm. Univ. 22:34-38. Zhong X, Shi CR, 1992. Research of Plankton and using it to monitor and assessment water quality in Hongfeng Lake Reservoir. Guizhou Environ. Protest. Sci. Technol. 2:64-69.

Zhou Q, Liao GH, Xue SR, 1987. Researcher of pollution control and water environmental quality assessment in Baihua Lake reservoir. Guizhou Environ. Protect Sci Technol. 2:35-52.

Ziv G, Baran E, Nam S, Rodríguez-Iturbe I, Levin SA, 2012. Trading-off fish biodiversity, food security, and hydropower in the Mekong River Basin. P. Natl. Acad. Sci. USA 109:5609-5614. 